\title{
Islamic Approach of Financial Inclusion for Sustaining Subsistence During the Pandemic
}

Farhat Nazirul Mubin Bohari, Muhammad Hilmi Mat Johar, Khairul Azhar Meerangani, Azreen Hamiza Abdul Aziz

To Link this Article: http://dx.doi.org/10.6007/IJARAFMS/v11-i3/10746 DOI:10.6007/IJARAFMS /v11-i3/10746

Received: 19 June 2021, Revised: 21 July 2021, Accepted: 04 August 2021

Published Online: 24 August 2021

In-Text Citation: (Bohari et al., 2021)

To Cite this Article: Bohari, F. N. M., Johar, M. H. M., Meerangani, K. A., \& Aziz, A. H. A. (2021). Islamic Approach of Financial Inclusion for Sustaining Subsistence During the Pandemic. International Journal of Academic Research in Accounting Finance and Management Sciences, 11(3), 377-394.

Copyright: @ 2021 The Author(s)

Published by Human Resource Management Academic Research Society (www.hrmars.com)

This article is published under the Creative Commons Attribution (CC BY 4.0) license. Anyone may reproduce, distribute, translate and create derivative works of this article (for both commercial and non-commercial purposes), subject to full attribution to the original publication and authors. The full terms of this license may be seen at: http://creativecommons.org/licences/by/4.0/legalcode

Vol. 11, No. 3, 2021, Pg. 377 - 394

Full Terms \& Conditions of access and use can be found at http://hrmars.com/index.php/pages/detail/publication-ethics 


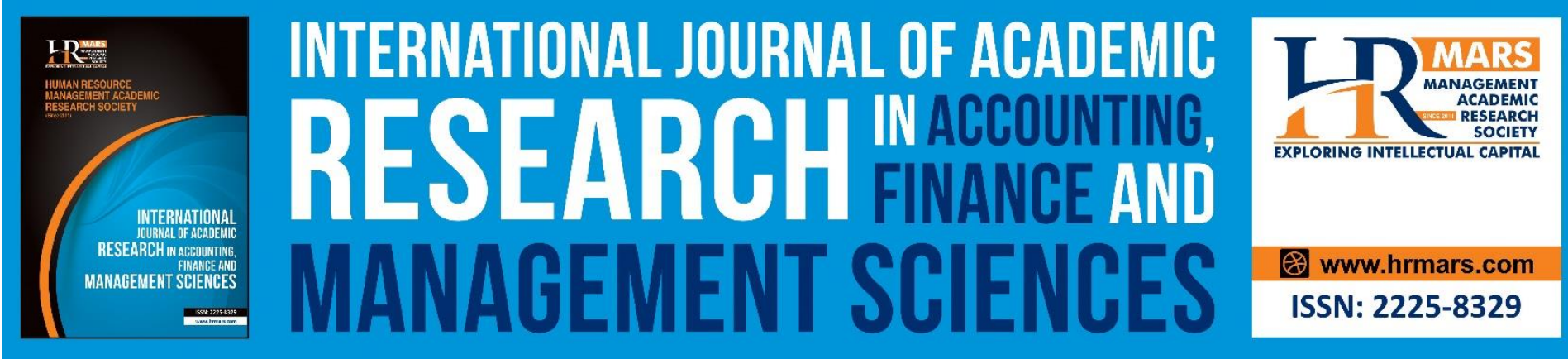

\title{
Islamic Approach of Financial Inclusion for Sustaining Subsistence During the Pandemic
}

\author{
Farhat Nazirul Mubin Bohari ${ }^{1}$, Muhammad Hilmi Mat Johar²,
} Khairul Azhar Meerangani ${ }^{3}$, Azreen Hamiza Abdul Aziz ${ }^{4}$

${ }^{1}$ Centre for Islamic Development Management (ISDEV), Universiti Sains Malaysia, Pulau Pinang, Malaysia, ${ }^{2}$ Faculty of Islamic Knowledge, Kolej Universiti Islam Melaka, 78200 Kuala

Sungai Baru, Melaka, Malaysia, ${ }^{3}$ Academy of Contemporary Islamic Studies, Universiti Teknologi MARA, UiTM Cawangan Melaka, Kampus Alor Gajah 78000 Alor Gajah, Melaka, Malaysia, ${ }^{4}$ Centre for Islamic Development Management (ISDEV), Universiti Sains Malaysia,

Pulau Pinang, Malaysia

Email: farhatnazirulmubinbohari@gmail.com, hilmi@kuim.edu.my, azharmeerangani@uitm.edu.my, azreenhamiza@usm.my

\begin{abstract}
The occurrence of COVID-19 pandemic has impacted all countries around the globe including Malaysia. The Malaysian GDP was decreased in 2020 due to the restriction on economic activity imposed by the government as a measure to contain the spread of COVID-19, directly affected many industries thus affected individuals working in the industries. Many have lost their jobs due to retrenchment or the closure of business. The number of unemployed individuals also has increased from525.2 thousand in February 2020 to 777.5 thousand in February 2021. Although the government provides aid for subsistence, the aid amount is far from the previous income of the affected individuals and given on periodic basis (not monthly) thus make it hard for the affected individuals to sustain subsistence. Hence, financial inclusion during the pandemic is a critical issue for the subsistence of the affected individuals. This study is a descriptive studyconducted to overcome the issue of financial inclusion on the affected individuals by the pandemic using Islamic approach that is free from riba in order to maximize the assistance that can be provided by the non-profit microfinance institutions (NMIs). Using the method of content analysis, the study found that there are three Islamic financing instruments suitable for financial inclusion during the pandemic which are Islamic microfinance, waqf and zakat. This study suggested these three Islamic financing instruments to be integrated with three financing methods that have been constructed which are full support financing, similar-build operate transfer (BOT) and similar-franchising. It is suggested for further research on the mechanism of each suggested financing methods. The approach of financial inclusion based on Islamic instruments is not for the purpose of profit, but rather to assist the affected individuals in becoming entrepreneurs and enables them to generate their own revenue for their own subsistence, thereby reducing the reliance on ongoing financial assistance by government. Simultaneously, financial inclusion for pandemic-affected
\end{abstract}


MANAGEMENT SCIENCES

Vol. 11, No. 3, 2021, E-ISSN: 2225-8329 @ 2021 HRMARS

individuals would help to preserve the local economy as well as the Malaysian economy as a whole.

Keywords: Financial Inclusion, Islamic Financing Instruments, Subsistence

\section{Introduction}

The coronavirus disease (COVID-19) is a pandemic that was first emerged in Wuhan, China in December 2019 and was spread all around the globe since then. Until June 2021, more than 170 million cases were reported worldwide with almost 4 million. In Malaysia, the first case of COVID-19 was reported in January 2020. Since then, 696,408 cases were reported with 4,408 deaths and the number is keep increasing. Not only it has caused many deaths, it also has affected various industry and economy sector ("Worldometers," n.d.). Before the emergence of COVID-19 in Malaysia, the recorded gross domestic product (GDP) at constant 2015 value in 2018 was MYR 1,363.8 billion and the value was increased by 4.4 percent in 2019 which was MYR 1,424.3 billion. After the emergence of COVID-19 in Malaysia, the GDP was decreased by 5.6 percent to MYR 1,343.9 billion in 2020 due to the restriction on economic activity imposed by the government as a measure to contain the spread of COVID19. This data shows that COVID-19 has a significant effect to Malaysian economy. In order to prevent the worsening of local economy, Malaysian government and local authorities have established various financial relief schemes to aid Malaysian households and businesses. Examples of the financial relief program by Malaysian government are Bantuan Prihatin Rakyat (BPR) and Geran Khas Prihatin (GKP) through Lembaga Hasil Dalam Negeri (LHDN) which is the Malaysian inland revenue board. BPR is a financial relief scheme focusing on Malaysian households and single individuals that falls under the B40 category. In addition to the BPR for Malaysia households and single individuals, Malaysian government also provides financial aids for small and medium enterprises (SME) under the scheme of GKP. In the GKP 1.0 and GKP 2.0, Malaysian government has provided a sum of MYR 3,000 for new eligible SMEs and in the GKP 3.0, the government has provided MYR 1,500 for new eligible SMEs. Malaysian government also provide additional aids of MYR 1,000 for the already eligible SMEs under GKP Permai scheme.

Although Malaysian government has provided financial aids to its citizens, the funds provided are insufficient for households and single individuals who have lost their jobs. In 2019, 508.2 thousand individuals were unemployed. This number has increased to 525.2 thousand in February 2020 which shows an increment of 3.3 percent. In February 2021, 777.5 thousand number of unemployed individuals were recorded. This shows that the number of individuals who lost their income since the emergence of COVID-19 in Malaysia can be assumed as according to the increment of 252.3 thousand number of unemployed individuals or 4.8 percent (Jabatan Perangkaan Malaysia, 2020) and this number is expected to increase in the future. The financial aids by Malaysian government to some extent help the affected individuals and households, but it is not sufficient as the financial aids is given once in a few months and the nature of the aids given is for expenses purposes.

Finding a new job can be very difficult during the pandemic as the movement control order (MCO) imposed by government restraints unemployed individuals' movement to find a job or to attend an interview (Rahman, Jasmin and Schmillen, 2020). Although the methods of online job application and online interview are available, it is going to be tough for these individuals to find a new place to live or rent if the job offered located in another city due to the MCO. In addition, the job offered in the private sector also has decreased due to business shutting down because of the pandemic. Looking at this situation, it is best for the affected 
MANAGEMENT SCIENCES

Vol. 11, No. 3, 2021, E-ISSN: 2225-8329 @ 2021 HRMARS

and unemployed individuals to start their own small businesses for their subsistence and to cater the needs of local market which affected by MCO, thus helping to sustain Malaysian economy. However, to start a business requires capital and the affected and unemployed individuals cannot provide the capital due to income loss caused by the pandemic. Hence, financial inclusion for the affected individuals is a critical issue, not only for Malaysians' survival but also for the sustainability of Malaysian economy.

The aim of this study is to assess the Islamic approach of financial inclusion for sustaining subsistence during the pandemic that suitable for the affected households and individuals. There are three main objectives of this study which are; firstly, to identify the Islamic approach of financial inclusion for sustaining subsistence during the pandemic; secondly, to analyze the Islamic approach of financial inclusion for sustaining subsistence during the pandemic; and thirdly, to conclude the Islamic approach of financial inclusion for sustaining subsistence during the pandemic. In order to achieve these objectives, research questions have been constructed accordingly as per below Table 3:

Table 3: Research Question Constructed Based on Research Objectives

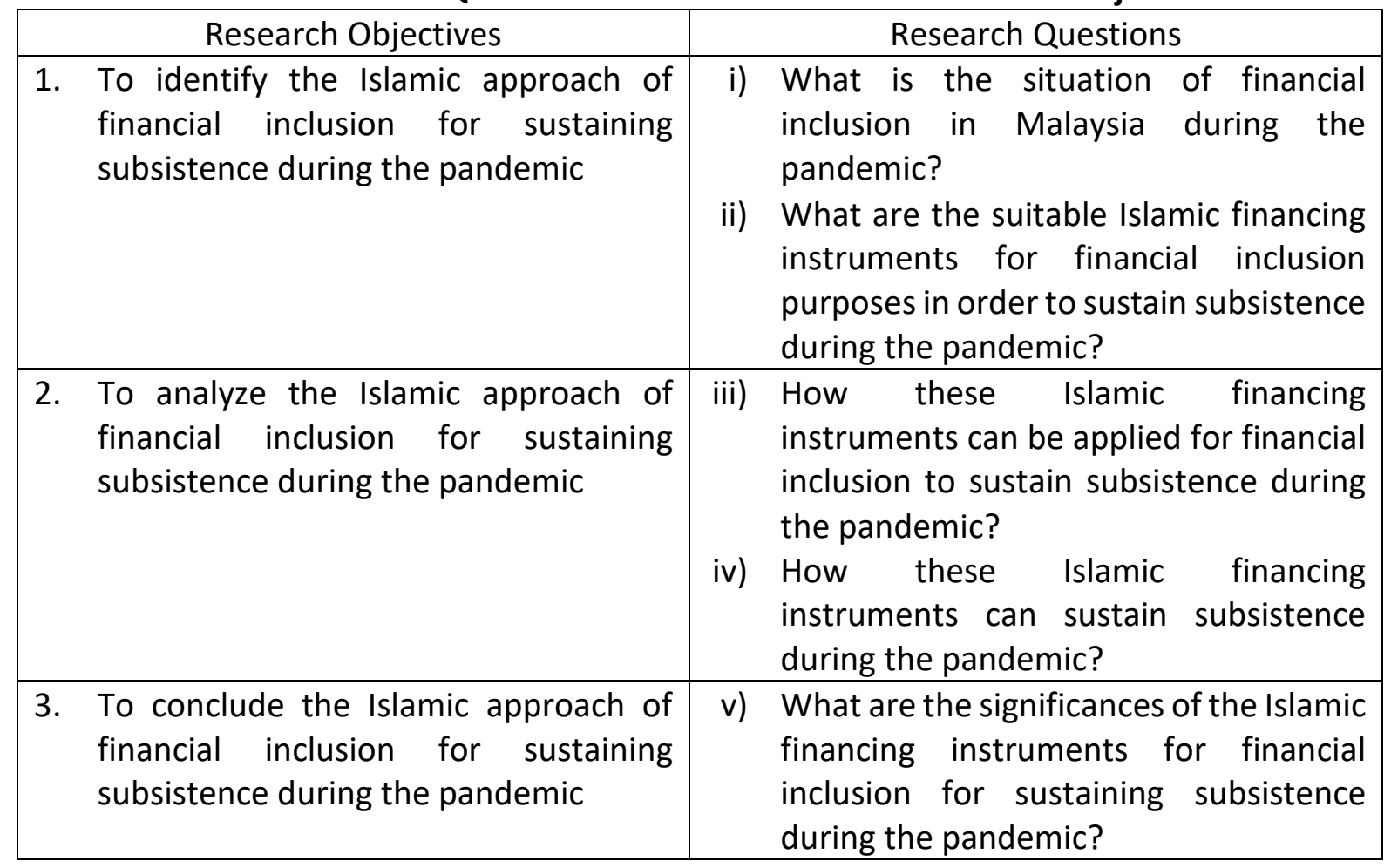

\section{Financial Inclusion in Malaysia During the Pandemic}

Subsistence is defined as the absolute minimum standard of productive life in a society (Sharif, 1986). It involves the act of individuals to support or maintain the minimum level of income for living. Business for subsistence is the establishment of enterprise to generate minimum required income to support oneself. Many have lost their income and being and unemployed during the pandemic COVID-19 and forced to establish microenterprises to get income-generating opportunities in order to maintain subsistence. However, financial inclusion is an issue as one may lack of collateral for financing purpose from banks and financial institutions. Financial inclusion is the accessibility of individuals and businesses to the available financial products that is beneficial to meet one's requirement. It is to provide 
MANAGEMENT SCIENCES

Vol. 11, No. 3, 2021, E-ISSN: 2225-8329 @ 2021 HRMARS

access and enables individuals and businesses to a formal credit market (Gopalan and Kikuchi, 2016).

Around the globe, there are organizations that have been established specifically to discuss the issues related to financial inclusion such as Alliance for Financial Inclusion (AFI), Association of Southeast Asian Nations (ASEAN) Working Committee on Financial Inclusion (WC-FINC), Global Partnership for Financial Inclusion (GPFI) and Consultative Group to Assist the Poor (CGAP). AFI is a policy leadership coalition formed by member central banks and financial regulatory institutions with a common goal of increasing financial inclusion on national, regional, and global scale. Through its cooperative strategy which incorporates peer learning, information exchange, and peer transformation, AFI partners with regulators, international organizations, and business sector leaders to generate practical solutions and enable the implementation of significant policy reforms ("Alliance for Financial Inclusion," n.d.). WC-FINC was established by ASEAN Central Bank and Finance Minister to promote and foster efforts in improving financial inclusion with four main objectives which are; firstly, to assist in the development and execution of a national financial inclusion strategy; secondly, to improve ASEAN Member States capacity building in order to improve the financial inclusion ecosystem; thirdly, to encourage creative financial inclusion through digital platforms; and fourthly, to raise financial inclusion and consumer protection knowledge ("Association of Southeast Asian Nations," n.d.). GPFI is a global platform for G20 countries, interested nonG20 countries, Implementing Partners, and Affiliated Partners to advance financial inclusion by increasing quality access to and use of sustainable formal financial services, thereby expanding opportunities for underserved and excluded households and enterprises as a means of sustaining development and ensuring well-being. In comparison to the previous organizations, interestingly, CGAP is an independent global organization with more than 30 members of leading development organization that strives to improve the lives of the poor by promoting financial inclusion. CGAP seeks to ensure that financial services are tailored to the needs of the poor, with a particular focus on women. Through knowledge and collaborations, CGAP encourages innovation, test ideas, and inspire change. CGAP provides assistance to individuals to get out of poverty, secure their gains, and advance global development goals by promoting responsible and inclusive financial systems ("Global Partnership for Financial Inclusion," n.d).

Central Bank of Malaysia (BNM) is working with AFI and WC-FINC for financial inclusion matters at international level. In addition, BNM also has teamed with the Fisher Committee on Central Bank Statistics, the OECD, and the World Bank to organize a variety of financial inclusion capacity building programs for policymakers around the world. BNM also is working with local banks to provide financial inclusion for SME. Local banks that involved in providing microfinancing for financial inclusion including Agrobank, Bank Rakyat, Bank Simpanan Nasional, Alliance Bank, Ambank, CIMB Bank, Bank Islam, Bank Muamalat, Maybank, Public Bank and United Overseas Bank ("Bank Negara Malaysia," n.d.). The products by these local banks have already been offered before the emergence of COVID-19 in Malaysia. Due to the pandemic, BNM has ordered banks and financial institutions in Malaysia to provide repayment assistance for individuals, microenterprises and SMEs that are not allowed to operate during the MCO. Borrowers who experienced income reduction are allowed to get monthly installments reduction. Individuals who lost their employment, individuals who are the recipients of Bantuan Sara Hidup (BSH) or Bantuan Prihatin Rakyat, microenterprises and SMEs including microenterprises that are not allowed to operate their business during the 
MANAGEMENT SCIENCES

Vol. 11, No. 3, 2021, E-ISSN: 2225-8329 ๔ 2021 HRMARS

$\mathrm{MCO}$ are allowed to take moratorium for three months or monthly installment reduction by 50\% ("Bank Negara Malaysia," n.d.).

BNM also has provided the Targeted Relief and Recovery Facilities (TRRF) as to support the recovery of SMEs. TRRF is a financial assistance for working capital purpose with up to MYR 500,000 for SMEs and up to MYR 75,000 for micro enterprises that available until December 31, 2021 or full utilization of MYR 6 billion. The assistance is meant for the SMEs in services including personal services such as repair of computers, household goods, laundry and beauty services; food and beverage services; human health and social work; arts, entertainment and recreation; wholesale and retail trade; and business services sector that affected by the reintroduction of MCO since June 2020. Beside of the financial aid specifically to support the recovery of SMEs due to MCO, BNM also continues to provide various financing assistance for SMEs through the participating financial institutions although the COVID-19 pandemic is happening. The financing assistances are as per below ("Bank Negara Malaysia," n.d.):

a) High Tech Facility - National Investment Aspirations (HTF-NIA)

High Tech Facility - National Investment Aspirations (HTF-NIA) fund is established to support high tech and innovation-drive SMEs with high National Investment Aspirations (NIAs) scores which affected by the pandemic. With the maximum tenure of 7 years, the financial assistance is for the purpose of working capital and capital expenditure with up to MYR 1 million for working capital and up to MYR 5 million for capital expenditure or the combination of working capital and capital expenditure for each eligible SME under the subsectors of manufacturing and services subsectors such as electrical and electronics; chemicals including pharmaceuticals and refined petroleum); optical scientific and medical equipment; machinery and equipment including robotics, drones and Industry 4.0 technologies; transport equipment that involved in global supply chains or transitioning towards future mobility and green technology; information and communication (ICT); and research and development (R\&D) services. The funds are also offered to SMEs that participated in the Government program that engaged with R\&D and innovation for critical technologies defined in national blueprints, ranging from IR4.0-related technologies to green technology and biotechnology.

b) Disaster Relief Facility (DRF) 2021

DDRF 2021 fund is established to relieve the financial strain placed on the identified SMEs that was devastated by floods in order to allow the SMEs to continue operations. The purpose of financing is for working capital and the repair or replacement of business asset damaged by the disaster. The financing size is up to MYR 75,000 for microenterprises and up to MYR 500,000 for SMEs with the maximum tenure of 5 years.

c) Agrofood Facility (AF)

The objective of the establishment of AF fund is to increase agrofood production in Malaysia and for export purposes by providing financing with the maximum tenure of 8 years to SMEs that met the criteria set by BNM. The financing purposes are for capital expenditures, working capital and development of agrofood projects with maximum financing of MYR 5 million.

d) All Economic Sector (AES)

AES fund is established with the objective to assist growth and improve SMEs' access for financing across all economic sectors. SMEs are able to apply for maximum financing of MYR 
MANAGEMENT SCIENCES

Vol. 11, No. 3, 2021, E-ISSN: 2225-8329 @ 2021 HRMARS

5 million through the participating financial institutions. The maximum tenure of $A E S$ financing is 5 years.

\section{e) Micro Enterprises Facility (MEF)}

The MEF fund is established to improve the access of collateral-free financing for micro enterprises, including self-employed and gig workers on digital platform. The maximum financing tenure is 5 years and the maximum amount per microenterprise is MYR 50,000 with financing purposes of working capital and capital expenditure.

\section{f) SME Automation and Digitalization Facility (ADF)}

With the maximum financing amount of MYR 3 million and maximum tenure of 10 years, ADF fund is established to encourage eligible SMEs to automate processes and digitalize their operations in order to boost productivity and efficiency. The purposes of financing including for purchasing equipment, machinery, computer hardware and software, IT solutions and services, technology support services, and other intangible assets.

\section{g) PENJANA Tourism Fund}

The PENJANA Tourism Fund is available for eligible SMEs and microenterprises in the sector of core tourism such as tourism accommodation premises; travel agencies and tour operators; and transportation for tourists. The fund also is available for SMEs and microenterprises in the tourism related sector such as medical tourism; Meetings, Incentive, Conferences, Exhibitions (MICE) ecosystem; money services businesses (money changing operators); and tourism-related retail, recreation and wellness. The maximum financing amount and the maximum financing tenure are different depending of the financial institution that offers the PENJANA tourism fund. However, most of the participating financial institution offers financing to the eligible SMEs for maximum amount MYR 300,000 and eligible microenterprises for maximum amount of MYR 75,000 with maximum tenure of 7 years for both categories.

Based on the above discussion, although the COVID-19 pandemic is happening, the financial inclusion in Malaysia is able to reach the individuals with low level of income, microenterprises and SMEs. The involvement of BNM at international level of financial inclusion is able to assist in determining strategies and policies that can be implemented in the country while assisting financial inclusion of the international society at the same time. BNM through its significant roles as a central bank promotes financial assistance and aids through various local banks and financial institutions will be able to strengthen the financial inclusion in Malaysia.

\section{Islamic Financing Instruments for Financial Inclusion During the Pandemic}

COVID-19 pandemic has caused many lost their income due to retrenchment or business closure. Due to the situation, it is best for the individuals affected by the pandemic that intends to start a microenterprise for subsistence purpose to be at the lowest liabilities as possible. This subtopic will discuss about Islamic approach for financial inclusion during the pandemic using the Islamic financing instruments. Microcredit is a small loan provides by organizations that are generally non-government organizations (NGOs) not motivated by profit but to serve humanitarian, social, or cultural interests. Microcredit was developed in the efforts to alleviate poverty and it is usually targeting a group of people who have less 
access to financial inclusion. Meanwhile, microfinance is the extension of microcredit. It is a development strategy that provides financial and social intermediation. Financial intermediation entails the provision of savings, credit, and insurance services, whereas social intermediation entails the formation of citizen groups to express needs and concerns for policymakers to consider (Qudrat-I Elahi and Lutfor Rahman, 2006). In this study, microfinance will be the focus as it has a larger scope and not limited to a specific group of people. In addition, microcredit is also a part of microfinance.

As per BNM, microfinance is a mean of financing for small business loans up to MYR 50,000 for micro enterprises and self-employed individuals, not a personal loan ("Bank Negara Malaysia," n.d.). Conventional microfinance offers loan with up to 20 percent made the repayment by the less fortunate seems impossible. Nevertheless, interest-free loans provided by some institutions raise sustainability issues (Zulkhibri and Ismail, 2014). Microcredit borrowers, who are primarily the poor and hardcore poor (lower income group), have no collateral asset, no financial record, and no credit history, and microcredit institutions lack the resources to compel repayment through the legal system (Al Mamun et al., 2011). It is the same case for the affected individuals by pandemic who intends to establish a subsistence business with zero prior knowledge in business and no financial records.

Both conventional and Islamic microfinance have better financial inclusion position in reaching the less fortunate individuals who intend to improve their lives by setting up small business to generate income for them and their families. Microfinance is required in the market as the less fortunate individuals are lacking of collateral that necessary in a commercial loan application (Abdelkader and Salem, 2013). Both conventional and Islamic microfinance institutions are able to provide small loans for microenterprises that the establishment is for self-employment to generate income for subsistence. The difference between conventional and Islamic microfinance loan can be seen with the interest charged on the loan. Conventional microfinance loan has the possibility of charging fixed interest rate as microfinance charge the same base lending rate (BLR) while the charges incur in an Islamic microfinance loan is limited to administrative charges and no interest charges are allows as according to the principle of qardh al-hassan (Ali, 2014).

In Malaysia there are organizations such as Tabung Ekonomi Kumpulan Usahawan Niaga (TEKUN), Amanah Ikhtiar Malaysia (AIM) and Yayasan Usaha Maju (YUM) that able to provide small loan which parallel with Islamic microfinance that free from riba as the instrument for financial inclusion for SMEs in Malaysia (Kassim et al, 2019). These organizations were funded by Malaysian government to assist the development of SMEs and individuals who are in need of capital to generate income from economic activities. These organizations have existed long before the emergence of COVID-19 in Malaysia. Although the pandemic is still happening, these organizations continues to provide assistance to new microfinance applicants. Besides, these organizations also provide financial relief for the existing borrowers due to the pandemic situation. In a news report by Astro Awani, a live conversation on $1^{\text {st }}$ April 2020 between Astro Awani and the Director of AIM, Shamir Aziz stated that AIM offers repayment moratorium for eligible entrepreneurs that affected from the pandemic. In addition to the moratorium, AIM also has allowed the affected entrepreneurs to withdraw funds from the entrepreneur compulsory savings account ${ }^{1}$ for subsistence purposes ("Astro Awani," n.d.). TEKUN also offered moratorium for repayment

1 Compulsory savings account is the account where the monthly installment is paid by the entrepreneurs and the excess payment from the installment is kept. 
MANAGEMENT SCIENCES

Vol. 11, No. 3, 2021, E-ISSN: 2225-8329 @ 2021 HRMARS

and allowed withdrawal from the entrepreneurs' compulsory savings account ("Tabung Ekonomi Kumpulan Usahawan Niaga," n.d.).

Zakat and waqf institutions in Malaysia also play major roles in Malaysian financial inclusion. Zakat and cash waqf are able to be the resources for Islamic microfinance (Abdelkader and Salem, 2013; Ibrahim, 2018). Zakat and waqf institutions in Malaysia are mainly under the auspices of Majlis Agama Islam Negeri (MAIN)2 ${ }^{2}$. Zakat is derived from Arabic word (ز) literally means clean, pure, bloom, bless and flourish. By term, zakat means to clean the assets that is owned. As for the rich and wealthy, zakat is meant to clean oneself from niggardliness and stinginess (Jabatan Wakaf, Zakat dan Haji, 2012). The difference in the usage of zakat and waqf funds is that the zakat funds can only be used for asnaf category of people, while waqf funds can be used for all category of people.

There are MAIN institutions that provide entrepreneurship program using zakat funds that targeting asnaf $f^{3}$. The entrepreneurship program by MAIN Institutions has already launched years before the emergence of COVID-19 in Malaysia. Its main purpose is to help the asnaf category to alleviate out from poverty and improve their living standards through the establishment of microenterprises. MAIN Selangor through the Lembaga Zakat Selangor (LZS) introduced Transformasi Usahawan Asnaf (TUAS) which is an economic development program focusing on asnaf to improve their living standards. There are various forms of business that were assisted under the program such as mobile truck, sewing, distribution, burger, liquefied petroleum gas (LPG), public market, craft and midwifery programs (Ibrahim, 2018). Majlis Agama Islam Wilayah Persekutuan (MAIWP) introduced various zakat assistance scheme for asnaf including for asnaf development, protection, economy, education and society development. Under its economy program, zakat funds are provided for assistance such as business assistance and entrepreneurship guidance; agriculture, fisheries and livestock assistance; motorcycle assistance for the disabled (OKU); taxi hire purchase deposit assistance; and business vehicle deposit assistance ("Majlis Agama Islam Wilayah Persekutuan," n.d.).

Derived from Arabic word (وقف) waqf literally means to hold, to confine or to retain. By term, waqf is referring to any property that being retained by the waqif's ${ }^{4}$ right on the asset from any dealings of sale and purchase, inheritance, hibah and will while maintaining its physical resources. The waqf assets only can be used for philanthropic purposes for the society (JAWHAR, 2012). By history, Islamic tradition of waqf has contributed many to the development of Islam. Not only the poor, the rich also can enjoy the benefits of various type of waqf. Waqf can be categorized under movable and immovable; and productive and nonproductive waqf. Movable waqf are the waqf assets that lightweight and can be carry around such as Quran and cash. Vice versa, immovable waqf are heavy physically and cannot be moved easily such as building and land. Productive waqf are referring to the waqf assets that are able to generate additional waqf assets. Renting out a waqf building would create income in the form of cash waqf which can be used later as a waqf asset. Unproductive waqf are referring to waqf assets that will not generate any income such as book, computer and praying mat (Bohari, 2016). The management of waqf assets in Malaysia are not limited to MAINs only. Although it is mainly being managed by MAINs, MAINs by its authority is able to

2 MAIN is the state Islamic religious council in Malaysia. There are 14 MAIN in Malaysia, 1 MAIN each state (13) and 1 in the federal territory.

3 The eligible group of people to receive zakat aid.

$4 \quad$ The person who waqf the asset. 
MANAGEMENT SCIENCES

Vol. 11, No. 3, 2021, E-ISSN: 2225-8329 @ 2021 HRMARS

appoint other institutions as a mutawalli to control and manage waqf assets. Pusat Pembangunan Pembiayaan Waqaf (PPPW) USIM which now is known as Pusat Wakaf dan Zakat (PWZ) USIM has been established in February 2013 and has been appointed by MAIN Negeri Sembilan as mutawalli in July 2013 to manage waqf funds and its main foci are on the sector of education and healthcare (Hasbullah et al., 2019).

The application of cash waqf as a financing resources can be tracked back since the first century where Umar (RA) gave a land in Khaibar for waqf which the yield is used for the needy, poor, kinsmen and guests ${ }^{5}$. During the Ottoman period, Yaci Haci Muslihuddin waqf his stores in Ağaç Pazarı and 10,000 akçe for lending purposes with a ten percent annual interest rate, generating cash income to pay three people for daily Quran reading at Kilise Mosque in 1423. Balaban Paşa who was an Ottoman district officer established larger waqf in 1442 to build mosque, imaret and school which construction, maintenance and staffing were using income generated from four shops, bathhouse and a sum of 30,000 akçe in cash. The cash waqf of 30,000 akçe is used for loan at ten percent interest annually. The application of cash waqf for loan to generate income through its annual interest became controversial in the mid-sixteenth century (Mandaville, 1979). Although it was controversial since it involves riba, using waqf funds for loan is an innovation in the Islamic financial system. The development of cash waqf application is rather new in comparison to Turkey. Waqaf An-Nur Corporation (WANCorp) that was appointed as mutawalli in the year of 2009 (Waqaf An-Nur Corporation, 2011). Other than healthcare sector as its main focus, WANCorp also has established Waqaf Dana Niaga (WDN) to provide financing assistance for entrepreneurs who are lack of capital using cash waqf that have been collected using qard al-hassan.

Based on the discussion above, below Figure 1 is constructed to explain the financial inclusion for sustaining subsistence during the pandemic using the identified Islamic financial instruments.

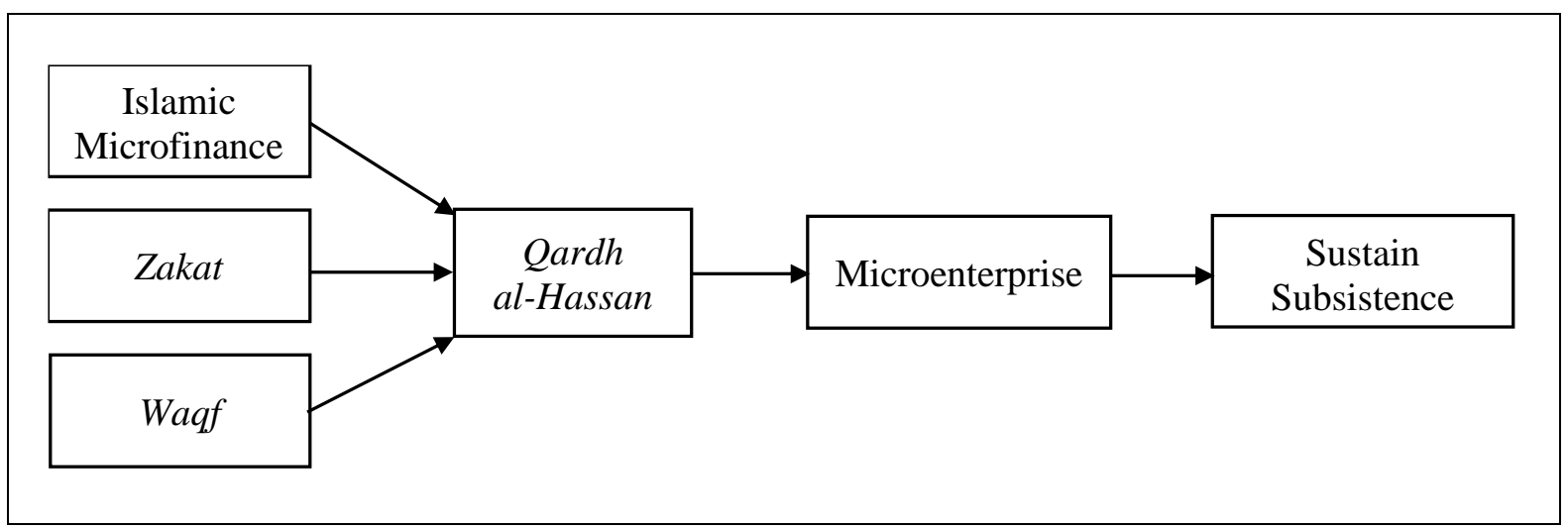

Figure 1: Financial Inclusion for Sustaining Subsistence During the Pandemic

Referring to the above Figure 1, the Islamic microfinance has been identified as a suitable Islamic financing instrument for the unfortunates to restart and rebuild their lives through the setup of subsistence microenterprises. In addition to Islamic microfinance, Islamic social finance instruments which are zakat and waqf also have been identified as suitable Islamic financing instruments. However, considering the pandemic situation that is happening, these instruments are most beneficial to be conducted with qard al-hassan 
MANAGEMENT SCIENCES

Vol. 11, No. 3, 2021, E-ISSN: 2225-8329 @ 2021 HRMARS

contract as it is able to reduce the burden of liabilities for Malaysians who were degraded from employed to being unemployed that intends to create income for subsistence purposes.

\section{Financing Method of Islamic Financing Instruments for Subsistence During the Pandemic}

Three Islamic financing instruments have been identified for financial inclusion in sustaining subsistence during the pandemic which are Islamic microfinance, zakat and waqf along with the application of qard al-hassan contract. Financing with these three instruments are suitable for financial inclusion during the pandemic because they offer the least liabilities. According to a study, AIM's microcredit services are not without fungibility concerns and payback problems. More than half of all respondents said they utilized credit for non-incomegenerating activities, which raises the likelihood of having a repayment difficulty. Borrowers may withdraw out of the program or become inactive borrowers as a result of repayment issues (Al Mamun et al., 2011).

Six financial components are crucial for a business well-being and survival which are; financial planning and control; financial accounting; working capital management; financial analysis; management accounting; and capital budgeting (Mohd Harif et al., 2010). Entrepreneurs need start-up experience to stimulate performance and for the long-term growth of their businesses. Making full use of previous expertise at the early stages of a firm makes it easier for businesses to achieve higher entrepreneurial performance (Peng et al., 2020). Due to lack of knowledge and expertise, the individuals who require assistance for setting up subsistence business may not have the best of abilities in running a microenterprise, which is why the method of financing these individuals are important. In this subtopic, the suitable financing method using the Islamic financing instruments for sustaining subsistence will be discussed.

\section{i) Full Support Financing}

Full support financing consists of full-fledge assistance in running a business including financial assistance and training scheme. Perbadanan Usahawan Nasional Berhad (PUNB) through its financing program offers financing amount from MYR 100 thousand to MYR 10 million with tenure up to 10 years. However, it is less favorable for the individuals affected by the pandemic as the profit rate for the financing plan is 5 to 8 percent profit rate annually. The financing scopes offered by PUNB are including working capital; renovation of business premises; tools and machinery; product registration, patent and copyright; product or process improvement; new market research; marketing and promotion; and domestic and international certification. PUNB provides business support in monitoring business performance through financial document review and audit, and platform for discussion and forums for business development. Entrepreneurial development course was established by PUNB for the formation of excellent entrepreneurial practices, values and culture among entrepreneurs. Besides, training and courses are provided to enhance the skills and knowledge of entrepreneurs in the areas of financial management, marketing, corporate governance and general management ("Permodalan Usahawan Nasional Berhad," n.d.).

The method adopt by LZS through TUAS is very suitable for the affected individuals. LZS provides capital and courses for TUAS entrepreneurs. Capitals are given in the form of grant from MYR 1,000 to MYR 5,000 which require no repayment. The courses are divided into three which are the management, technical skill and spiritual. Management courses provided including entrepreneurship, finance and marketing. As for technical skills, the entrepreneur may join courses related to the business such as cooking and sewing. Spiritual 
MANAGEMENT SCIENCES

Vol. 11, No. 3, 2021, E-ISSN: 2225-8329 @ 2021 HRMARS

courses are also provided for motivation purposes (Ibrahim, 2018). Although zakat funds are only meant for asnaf category, the same method of financing can be applied by other NMIs to provide assistance to the affected individuals by the pandemic.

Referring to the microfinancing offered by PUNB, the financing and training scheme are suitable to meet the needs of the affected individuals who intends to build their own business but lacks of knowledge and experience, except it involves a sum of profit based on the profit rate of the financing. Zakat funds only focusing on eligible category of people (asnaf). The process of identifying an individual asnaf status is time consuming, meanwhile the affected individuals require urgent assistance. In addition, zakat funds are limited and the use of zakat funds are not limited to only in assisting developing business for the asnaf. Hence, the same method that is used by LZS may be adopted by other non-profit microfinance institutions (NMIs). Although LZS give the capital require in the form of grant, NMIs may offer the financing scheme with repayment with qardh al-hassan. Repayment is an important element in providing financial assistance to the affected individual as it can serves as a motivation for the continuity of the business and as a resource of funds to assist other affected individuals. Below Figure 2 is to explain the full support financing that are suitable for the affected individuals:

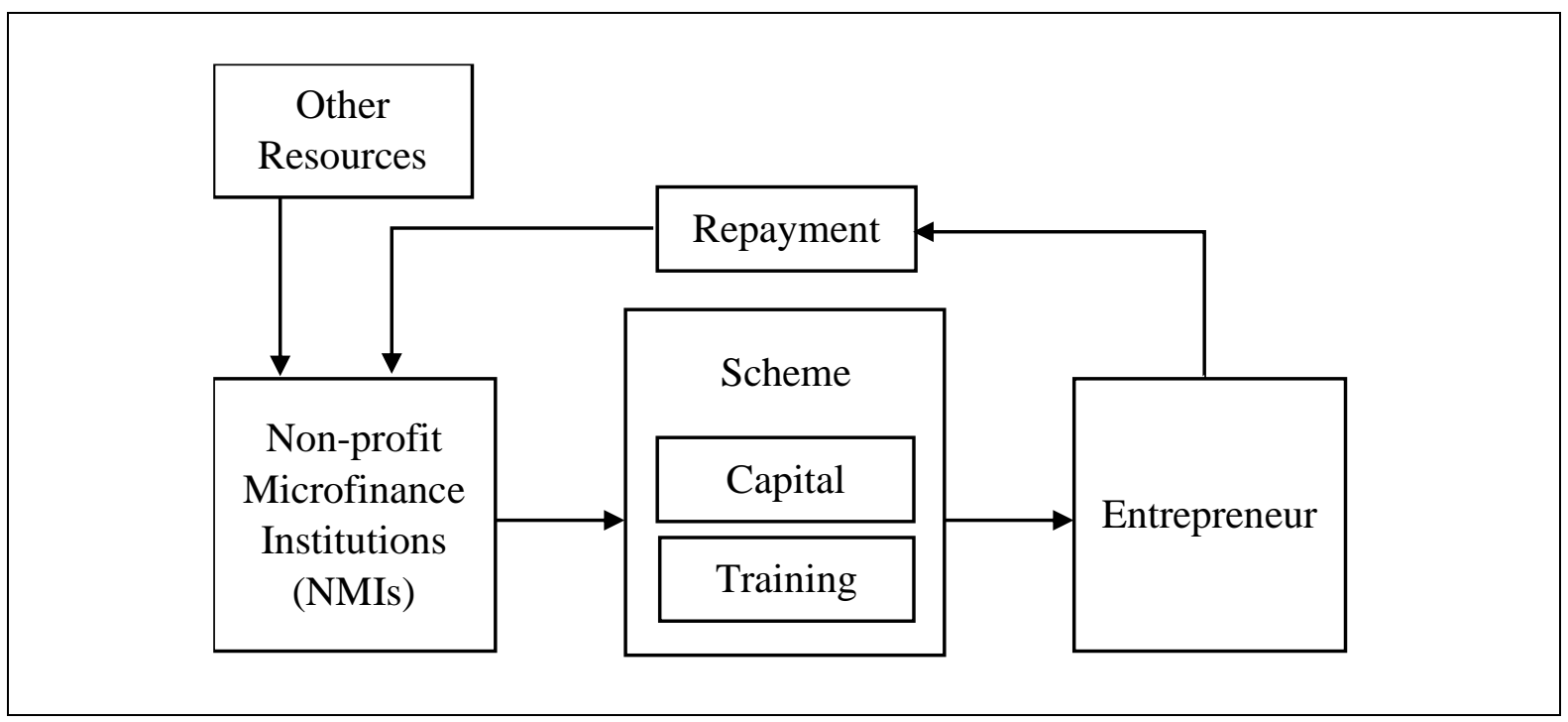

Figure 2: Full Support Financing Method

Referring to the Figure 2 above, the NMIs are the party that provide financing scheme including capital and training to the entrepreneur or the affected individual by pandemic. Capital is including working capital and capital goods such as machinery, tool and equipment. Meanwhile, training consists of management training such as marketing and finance; technical and skills training to sharpen the entrepreneurs' business-related skills; and motivation sessions to motivate the entrepreneurs to keep their momentum in doing business. Profit obtained from the business is then use for repayment based on percentage set by the NMIs. The funds received from the repayment along with other resources is used to finance new applicants of the scheme. Other resources on the above figure is depending on the type of NMIs. If the NMIs are the NGOs, the other resources would be the funds received from government, private sector institutions and crowdfunding. If the NMIs are zakat institutions, the other resources would be zakat funds solely which can only be use for asnaf category of entrepreneur which can be used to finance the affected individuals that 
MANAGEMENT SCIENCES

Vol. 11, No. 3, 2021, E-ISSN: 2225-8329 @ 2021 HRMARS

became asnaf due to the pandemic. As for the NMIs that are waqf institutions, the other resources would be waqf funds obtained from crowdfunding and income generated from waqf assets. This method of financing is better suited to entrepreneurs that have their own vision and business-related skills but limited amount of experience and business expertise such as car workshop, motorcycle workshop and tailor shop. With guidance and trainings, a business can be built and will be able to generate income and sustain subsistence for the affected individuals participated as entrepreneurs in the scheme.

\section{ii) Similar-Build Operate Transfer (BOT) Financing}

Build-Operate-Transfer (BOT) is a legal strategy used to finance large projects for public infrastructure such as toll motorways, trains, ports, and bridges as part of a Public Private Partnership (PPP). The government will award a concession to a private entity to fund, develop, and run a project under a build-operate-transfer (BOT) contract for a set period of time to obtain its return on investment before the transfer of project ownership to the government. There are a few successful BOT projects in Malaysia such as Projek Lebuhraya Utara Selatan (PLUS) highway, Lekir Bulk Terminal (LBT), Shah Alam Expressway (SAE), Tanjung Pelepas Port (TPP), East Coast Expressway, Tun Salahuddin Bridge and Johor Eastern Dispersal Link Expressway (EDL Expressway) (Markom and Ali, 2012).

Based on the BOT method, a similar-BOT can be applied to establish subsistence business as a financing method for the individuals affected by pandemic. Figure 3 below is to explain the mechanism of a similar-BOT:

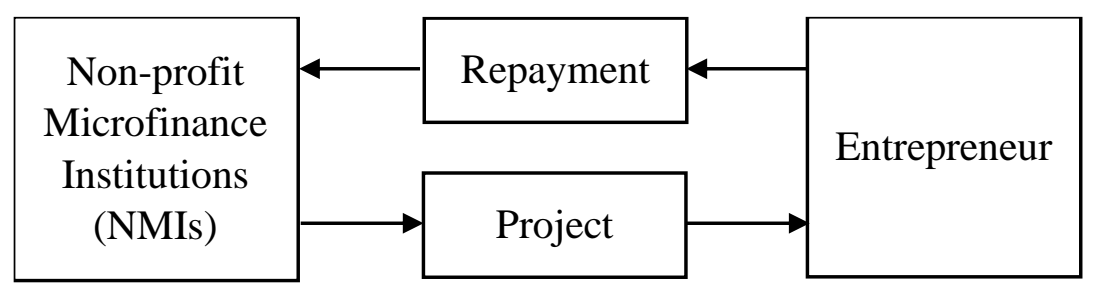

Figure 3: Similar- Build Operate Transfer (BOT) Financing Method

Similar to a private entity in BOT, NMIs using its own resources to finance and build a business project as a ready-to-run business for the entrepreneurs. The transfer of knowledge happens once the project is completed. In comparison to a BOT, the positioning of the entrepreneurs is similar to government except the entrepreneurs does not hold any authority or assets for the project but instead, the entrepreneurs are receiving aids from the NMIs. The government awards a concession contract to the private entity in BOT but in the similar-BOT financing, the entrepreneurs are only required to make repayment based on qardh al-hassan for a certain period of time to cover for the business building cost. This type of financing is suitable to entrepreneurs that have their own vision and many business experiences but without any business-related skills. The entrepreneurs are able to make their own brand which may be developed into a bigger scale of business. NMIs build the base for entrepreneur by using its resources to setup and prepare the business to the level of operatable by entrepreneur. However, the project must be a business that can be takeover easily by entrepreneur to run it independently and requires only a little set of skills and experience with less monitoring and guidance which the transfer of knowledge process including trainings for operating the 
MANAGEMENT SCIENCES

Vol. 11, No. 3, 2021, E-ISSN: 2225-8329 @ 2021 HRMARS

business can be done quickly. Fast-food and drink stalls are the example of appropriate business projects to fund using this method. Considering the entrepreneur's vision to develop the business, there is possibility of business expanding and branches opening in the future after the financing period is finished.

\section{iii) Similar-Franchising Financing}

Franchising is a method of distributing products or services that involves a franchisor, who establishes the brand's trademark or trade name as well as a business system, and a franchisee, who pays a royalty and, in many cases, an initial fee for the right to do business under the franchisor's name and system (Blair and Lafontaine, 2005). Franchising and licensing are using a company's intellectual capital that consists of human capital, intellectual property and relationship capital to create new income streams, market possibilities, and profit centers (Sherman, 2011).

It is important to understand the key components of the foundation of franchising which are a proven prototype location; strong management; sufficient capitalization; distinctive and protected trade identity; proprietary and proven methods of operation and management; comprehensive training programs for franchisees; field support staff; comprehensive legal documents; demonstrated market demand; uniform site selection criteria and architectural standards; genuine understanding of the competition; relationships with key resources; franchisee profile and screening system; effective reporting and recordkeeping system; research and development capabilities; communication system; and national, regional, and local advertising, marketing, and public relations programs (Sherman, 2011).

Franchising is less capital intensive than internal expansion of a business (Sherman, 2011). However, in this method of similar-franchising, it is a capital intensive for the franchisor (the NMIs) because it is similar to the internal expansion of a business. In a typical franchising business, franchisor will set an amount of initial capital requirements for the franchisee to obtain the license (Blair and Lafontaine, 2005). In similar-franchising financing, not only it requires the franchisor capital to setup its own franchisor business, but also the capital for its franchisee whom are the affected individuals (entrepreneurs). A franchisor of a similarfranchising financing method, requires the same amount capital as if the franchisor develop its own branches without using franchising approach. Figure 4 below is to explain the similarfranchising method to finance the affected individuals by pandemic in setting up a subsistence business:

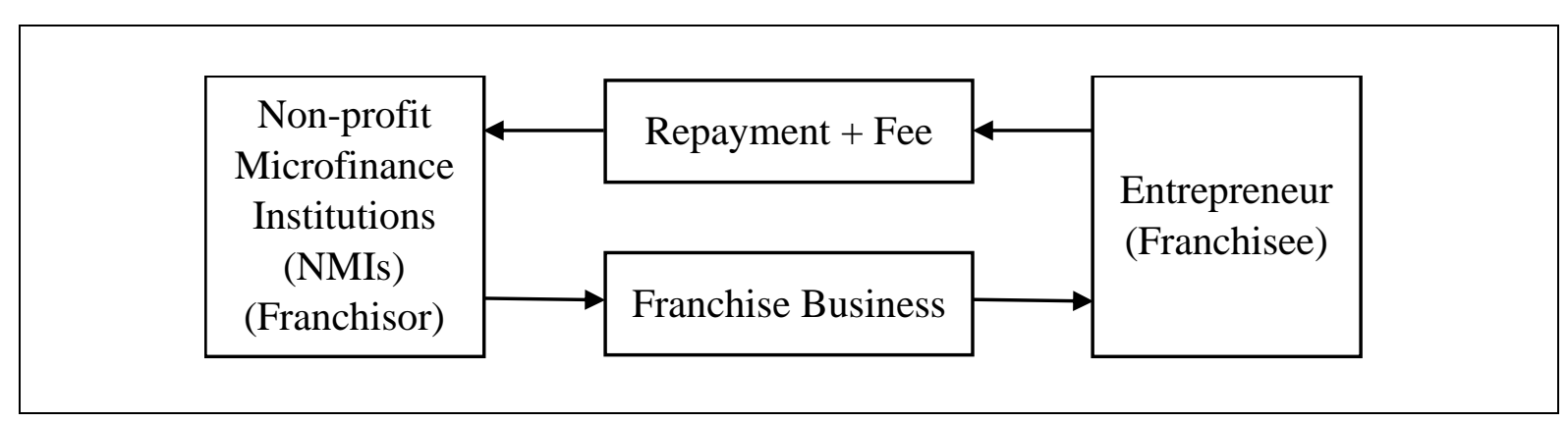

Figure 3: Similar-Franchising Financing Method

Using its own resources, NMIs as the franchisor setup a solid business with its own brand, trademark, product, marketing and standard operating manual as a business 
MANAGEMENT SCIENCES

Vol. 11, No. 3, 2021, E-ISSN: 2225-8329 @ 2021 HRMARS

benchmark and guideline for the entrepreneur. The business must be an easy-to-operate business such as fast food and drink stall that are suitable to operate in local vicinity of the entrepreneur. NMIs are then is to select the eligible entrepreneur to be its franchisee based on the criteria set by NMIs and provide adequate training to the entrepreneur before the franchisee receive the license to operate the franchise. NMIs provide the capital including working capital, stall and equipment. Continuous training may be provided as per product development and continuous monitoring are required. Continuous product development, marketing and promotion are the responsibility of the NMIs. The entrepreneur as the franchisee is then make repayment to the NMIs on monthly basis under the qardh al-hasan contract along with the franchise fee.

Based on the discussion above, three methods for financing using the Islamic financial instruments have been identified which are full support financing, similar-BOT financing and franchising financing. Full support financing is suitable for entrepreneurs that have businessrelated skills but lack in business management. Although the entrepreneurs might be lacking with the business-related, the entrepreneurs can be trained because a subsistence purpose business only requires basic skills as in daily life such as sewing and baking. Through training and practice, the skills can be improved. Similar-BOT and similar-franchising financing methods are suitable for entrepreneurs with experience and knowledge in managing a business and the business does not require any specific skill. The same business category can be setup using the similar-BOT or similar-franchising financing but the difference is that the entrepreneurs can build their own brand with their own management and marketing strategy. Also, the entrepreneurs require less monitoring and guidance by the NMIs. On the other hand, although the same business setup is provided, the similar-franchising financing method requires more attention from the NMIs as the entrepreneurs are require to follow NMIs operating standard because the NMIs are the franchisor. Each of the franchising method are meant for different category of entrepreneurs in terms of knowledge, experience and skills. NMIs need to be careful in selecting the affected individuals by pandemic as the entrepreneurs to be financed using the methods above.

\section{Conclusion}

The pandemic COVID-19 has affected all the people around the globe regardless of social status. Many have lost their income status. As for Malaysians, although there is various financial aid scheme provided by the central government, state government and local organizations, the aid provided are not enough to cover for monthly expenses especially to those who experience retrenchment that have many monthly commitments. In addition, after a period of time, the organizations that providing the aids will have to reduce the assistance amount due to the decrease of funds available as the pandemic continues. The citizens cannot depend on the aids due to this factor. Hence, financial inclusion for the affected individuals is an important topic to ensure the subsistence of the affected individuals and households, and to enable them to independently generate their own income. The identified Islamic financial instruments which are Islamic microfinance, zakat and waqf are able to overcome the financial inclusion issue of the affected individuals. Using the Islamic financial instruments, the study suggested three financing method for the subsistence of the affected individuals during the pandemic which are full support financing, similar-BOT financing and similarfranchising financing considering the factors that the affected individuals may lack in the foundation of business knowledge, or business-related skills, or experience, or all of the foundations. 
MANAGEMENT SCIENCES

Vol. 11, No. 3, 2021, E-ISSN: 2225-8329 @ 2021 HRMARS

Give a man a fish, you feed him for a day. Teach a man how to fish, you feed him for his life. The approach of financial inclusion using the Islamic instruments are not for profit, but solely to assist the affected individuals to become entrepreneur and generate their own income for their own subsistence with growth potential, thus to reduce their dependence on continuous financial aids. At the same time, the financial inclusion for the affected individuals by pandemic will be beneficial for sustaining the local economy as well as the Malaysian economy as a whole.

Financial inclusion is a critical issue currently due to many was affected by the pandemic because of retrenchment, business closure and the increase of unemployment rate. This study discovered that the Islamic strategy of financial inclusion, which employs the instruments of Islamic microfinance, waqf, and zakat, can help the affected individuals because these instruments were effective in assisting poverty alleviation prior to the pandemic. Theoretically, this study suggests the application of three financing methods which are full-support financing, similar-BOT financing and similar-franchising on the three instruments to maximize its ability in providing assistance for sustaining subsistence of the affected individuals. Full-support financing is a typical method of financing that can be found before the pandemic. Similar-BOT and similar-franchising as per its name, are not exactly a BOT and franchising, but similar as per above discussion. These methods of financing can be offered to affected individuals who have the capabilities in term of skills or management as per discussed in the study. By using these methods according to the capabilities of the affected individuals, the assistance provided by NMIs can be more effective with potential growth in the future.

\section{Acknowledgement}

This research received no specific grant from any funding agency in the public, commercial or not-for-profit sectors.

\section{Corresponding Author}

Muhammad Hilmi Bin Mat Johar

Faculty of Islamic Knowledge, Kolej Universiti Islam Melaka

Email: hilmi@kuim.edu.my

\section{References}

Abdelkader, I. B., \& Salem, A. B. (2013). Islamic vs conventional microfinance institutions: performance analysis in MENA countries. International Journal of Business and Social Research (IJBSR), 3(5), 219-233.

Al Mamun, A., Abdul Wahab, S., Malarvizhi, C. A., \& Mariapun, S. (2011). Examining the critical factors affecting the repayment of microcredit provided by Amanah Ikhtiar Malaysia. International Business Research, 4(2), 93-102.

Ali, K. M. (2014). Integrating Zakah, Awqaf and Islamic microfinance for poverty alleviation: three models of Islamic micro finance. IRTI Working Paper Series for Islamic Research and Training Institute.

Alliance for Financial Inclusion. (n.d.). Retrieved on June 23, 2021, from AFI website: https://www.afi-global.org/

Association of Southeast Asian Nations. (n.d.). Retrieved on June 23, 2021, from ASEAN website: https://asean.org/ 
MANAGEMENT SCIENCES

Vol. 11, No. 3, 2021, E-ISSN: 2225-8329 ๔ 2021 HRMARS

Astro Awani. (n.d.). Retrieved on June 23, 2021, from Astro Awani website: https://www.astroawani.com/video-malaysia/covid-19-kesan-langsung-kepadasahabat-amanah-ikhtiar-malaysia-1841116/

Aziz, A. R. A. (2020). Pengangguran dalam kalangan Tenaga Kerja Semasa Wabak COVID19. Malaysian Journal of Social Sciences and Humanities (MJSSH), 5(11), 1-9.

Bank Negara Malaysia. (n.d.). Retrieved on June 23, 2021, from BNM website: https://www.bnm.gov.my/documents/20124/55792/18062020_Pembiayaan+Mikro+ Comparative+Table+\%282020\%29-EN.pdf

Bank Negara Malaysia. (n.d.). Retrieved on June 24, 2021, from BNM website: https://www.bnm.gov.my/o/covid-19/ra_en.html

Bank Negara Malaysia. (n.d.). Retrieved on June 24, 2021, from BNM website: https://www.bnm.gov.my/o/covid-19/index.html

Bank Negara Malaysia. (n.d.). Retrieved on July 15, 2021, from BNM website: https://www.bnm.gov.my/documents/20124/764825/FAQs+on+Pembiayaan+Mikro+ April+.pdf

Blair, R. D., \& Lafontaine, F. (2005). The economics of franchising. Cambridge University Press.

Bohari, F. N. M. (2016). The potential of healthcare waqf in Malaysia (master's thesis). Universiti Sains Malaysia, Pulau Pinang, Malaysia.

Consultative Group to Assist the Poor. (n.d). Retrieved on June 23, 2021, from CGAP website: https://www.cgap.org/

Global Partnership for Financial Inclusion. (n.d). Retrieved on June 23, 2021, from GPFI website: https://www.gpfi.org/

Gopalan, S., \& Kikuchi, T. (Eds.). (2016). Financial inclusion in Asia: Issues and policy concerns. Springer.

Hasbullah, M., Ismail, W. A. F. W., Alias, M. H., \& Johari, F. (2019). Challenges in the Establishment and Implementation of Waqf in Public Institutions of Higher Learning: USIM's Experience. In M. Y. Ali Basah, S. Abdul Hamid, N. H. Hashim, N. Ahmad, Z. Zulkefli (Eds.), Sustainable Social and Economic Well-Being (pp. 514-517).

Ibrahim, M. A. (2018). Pembiayaan mikro dalam kalangan usahawan asnaf di Lembaga Zakat Selangor (LZS) (Doctoral dissertation). Universiti Sains Malaysia, Pulau Pinang, Malaysia.

Jabatan Perangkaan Malaysia. (2020). Household income and basic amenities survey report 2019. Jabatan Perangkaan Malaysia.

Jabatan Perangkaan Malaysia. (2021, February). Statistik utama tenaga buruh di malaysia. Jabatan Perangkaan Malaysia.

Wakaf, J., Haji, Z. D. (2012). Kompilasi hukum dan fatwa berkaitan wakaf, zakat, haji and sumber am. Jabatan Perdana Menteri. Putrajaya.

Majlis Agama Islam Wilayah Persekutuan. (n.d.). Retrieved on July 14, 2021 from MAIWP website: https://www.maiwp.gov.my/i/index.php/en/jenis-skim-bantuan-zakat

Markom, R., \& Ali, E. R. A. E. (2012). A legal analysis of successful and problematic build, operate and transfer (BOT) projects in Malaysia. International Journal of Business and Society, 13(2), 133.

Harif, M. A. A., Osman, H., \& Hoe, C. H. (2010). Financial management practices: An in-depth study among the CEO of Small and Medium Enterprise (SMEs). International Review of Business Research Papers, 6(6), 13-35.

Permodalan Usahawan Nasional Berhad. (n.d.). Retrieved on July 15, 2021 from PUNB website: https://www.punb.com.my/ms/pembangunan-usahawan-latihan 
Rahman, A. A., Jasmin, A. F., \& Schmillen, A. (2020). The vulnerability of jobs to COVID-19: the case of Malaysia. Economic Working Paper, 2020-09.

Sharif, M. (1986). The concept and measurement of subsistence: a survey of the literature. World Development, 14(5), 555-577.

Sherman, A. (2011). Franchising and Licensing: two powerful ways to grow your business in any economy. Amacom.

Tabung Ekonomi Kumpulan Usahawan Niaga. (n.d.). Retrieved on June 23, 2021, from TEKUN website: https://www.tekun.gov.my/ms/inisiatif-tekun-covid19/

Waqaf An-Nur Corporation. (2011). Laporan tahunan 2010. Johor, Malaysia.

Worldometers. (n.d.). Retrieved on June 21, 2021, from worldometer website: https://www.worldometers.info/coronavirus/

Zulkhibri, M., \& Ismail, A. G. (Eds.). (2017). Financial Inclusion and Poverty Alleviation: Perspectives from Islamic Institutions and Instruments. Springer. 